\title{
Human Fetal Tissue
}

National Cancer Institute

\section{Source}

National Cancer Institute. Human Fetal Tissue. NCI Thesaurus. Code C18841.

Any tissue from a human fetus. 